\title{
The Husband's Obligation in Giving Religious Education for His Wife According to Compilation of Islamic Law and Its Implementation on Tablighi Jama'at in Serdang Bedagai, North Sumatra, Indonesia
}

\author{
Ibnu Radwan Siddik T, MA \\ Faculty of Shari'ah and Law, State Islamic University of North Sumatra (UINSU, Medan), Indonesia
}

\begin{abstract}
In accordance to the provisions of Article 80 verse (3) Compilation of Islamic Law (KHI), a husband must provide religious education to his wife and gave the opportunity to learn the knowledge that is useful and beneficial to religion, homeland and nation. In reality, the husband sometimes pay less attention to this obligation, they devote more attention to the fulfillment of the obligations of a living material such as clothing, food and home to their wives. Tablighi Jama'at is one of the missionary movement in Serdang Bedagai, North Sumatra. One of the characteristics of this missionary movement is in preaching they leave their families (wives and children) to bring their own funds to another place within 3 days, 40 days and 4 months. This study tried to find out how husbands who are members of Tablighi Jama'at in fulfilling their duty to provide religious education to his wife on the sidelines of their missionary activity. Do They implement the obligation in accordance with a compilation of Islamic law or not. This research is a sociological study with qualitative analysis techniques. The sampling was based on purposive sampling with certain criteria. The results showed that the duty of the husband to give to his wife's religious knowledge well implemented among members of Tablighi Jama'at in Serdang Bedagai, North Sumatra. Tablighis members held ta'lim in the home every day, muzakarah (discussion) and always advised their wives. This is a way of transfer of religious education from husband to wife. Not only provide religious education, the husbands also provide an opportunity to learn the religion to their wife through the program khuruj masturah within 3 days, 15 days or 40 days.
\end{abstract}

Keywords: husband's obligation, compilation of Islamic Law, Tablighi Jama'at, khuruj masturah

\section{INTRODUCTION}

As a result of the formation of a marriage bond, then generate what is called the rights and obligations of husband and wife. Right can be interpreted simply with everything you need or deserve owned or in the can by a person, while the obligation is something that should be done or accomplished by someone. What is the duty of the husband in essence is the right of the wife, and vice versa, what is the obligation of the wife is the right of the husband. The provisions on what is the duty of a husband against his wife have been described both in the Qur'an and the Hadith of the Prophet. Al-Qur'an obliges husband gave sustenance in the form of food and clothing in a good way according to his ability (Surah Al-Baqarah, verse (233). Husband also demanded providing shelter and not making troublesome to his wife. (Surah Al-Talaq, verse (6). in a Hadith narrated by Abu Daud, mentioned that among the obligations of a husband against his wife is giving of the clothes, did not hit his face and did not reproach him. (Sulaiman, tt: 606).

The Compilation of Islamic Law (KHI) is one source of Islamic family law in Indonesia in accordance with Presidential Instruction No. 1/1991. As the source material law, KHI also stipulates the rights and obligations of husband and wife. Liabilities associated with the husband on the wife, in article $80 \mathrm{KHI}$ explained that among the obligations of a husband is to guide, protect, and provide religious education to the wife. Then the husband also bear a living, kiswah, shelter, household expenses, cost of care, treatment and education for their wives and children. What is interesting to observe from above is the duty of the husband with regard to religious education on the wife. In Article 80 verse (3) mentioned. "The husband must provide religious education to his wife and provide an opportunity to learn useful knowledge that is beneficial to religion, homeland and nation." It was a husband, in addition to the obligation to provide a living enacting and general already understood by society, it is also an obligation to provide religious education to his wife. A husband is required to direct his wife to be able to run the rule of Islam by providing religious guidance to his wife and provide an opportunity to learn useful knowledge for her life. Tablighis is one group of missionary movement that developed in Indonesia at this time. Tablighis, which originally grown in India, evolving rapidly across Muslim countries in the world, is no exception Indonesia. In Indonesia, the core group has been followed by the Muslim society to each of the provinces, districts, sub-districts and villages, is no exception Bedagai Serdang, 
North Sumatra. This Jama'ah proselytizing later called the khuruj fi sabilillah by spending time out preaching from one mosque to another mosque in every village, town and across the country. Tablighi Jama'at members were khuruj (out) have left the family (wife and children) at home by relying on their own expense to invite people to obey Allah's religion. The problem that arises is on the one hand a member of Tablighi Jama'at is as husband and head of the family, but on the other hand he left the family to preach in a long time. How they can fulfill their obligations as a husband? Are they able to implement the duty of the husband to provide religious knowledge to his wives, as desired by the Compilation of Islamic Law? What with being part of Tablighis they are constrained to fulfill these obligations? Presumably the questions is what makes researchers interested in studying this further in a scientific study.

\section{LITERATURE REVIEW}

The Marriage as a legal act between husband and wife, not just a means to realize the worship of God, but at the same time has consequences in civil law between both of them. in order to get the goal of marriage, namely to build a happy family, eternal and immutable, it is necessary to regulate the rights and obligations of the husband and wife respectively. If the rights and obligations of each husband and wife met, then the desire of husband and wife in the ark of the household will be realized, based on love and affection. (Rofiq, 1998: 181). In the Islamic family law in Indonesia, the provisions concerning the rights and obligations of husband and wife is regulated in the Marriage Law No. 1 of 1974 in Chapter VI of Article 30 to 34 and the Compilation of Islamic Law in Chapter XII of article 77 to 84 . For liabilities husband on the wife more systematic manner stipulated in Article 80 verse (1 s / d 7) Compilation of Islamic Law, which reads:

\section{Article $80 \mathrm{KHI}$}

1. The husband is a supervisor on the wife and her household, but on matters of domestic affairs to the essential decided by husband and wife together.

2. He shall protect his wife and provide every necessity of home life according to his ability.

3. The husband must provide religious education to his wife and provide an opportunity to learn useful knowledge that is beneficial to religion, homeland and nation.

4. In accordance with the incomes to bear her husband:

a. Living, kiswah and residence for the wife;

b. Household costs, maintenance costs and the cost of treatment for the wife and children;

c. The cost of education for children.

5. Obligations husband against his wife, as referred to in verse (4) a and b above shall take effect after a perfect tamkin of his wife.

6. A wife can free him from the obligation to him as referred to in verse (4) a and b.

7. Liability husband referred to in verse (5) void if wife is nusyuz.

In the verses of chapter $80 \mathrm{KHI}$ above in detail explained that among the duty of the husband to the wife is that the husband is obligated to protect his wife, giving religious education, in accordance with the income required to bear a living, kiswah, housing, cost of care and treatment and education expenses for their wives and children. The draw of the formula above is that a husband must provide religious education to his wife and provide an opportunity to learn useful knowledge that is beneficial to religion, homeland and nation. In reality in society, it is sometimes not a priority and something that is overlooked in family life. What a husband think is working diligently and how it can generate just as much money to give to his wife. Husband forget that he has a duty of great depth as to how he could become a priest, a leader for the wife and children in the field of religious guidance. Husbands should be able to provide religious education and a good example to his family. When a man is not able to provide religious education, then KHI explained that he could only give permission to his wife to study theology expert people for the sake of a wife. Often a household crack, and ended in divorce not the absence of an adequate income of a husband, but because there is no religious values are alive and thriving in their household. Ideally, a marriage was formed was to perform worship and religious enhance and revive religious values in family life.

Concern about the duty of a husband to guide and provide religious education either the wives or children, frequently mentioned in the Qur'an and Hadith. In Surat al-Tahrim verse (6), Allah says; "O ye who believe! Yourselves and your families from a Fire whose fuel is men and stones; guardian angels are rough and tough, who do not disobey Allah in what He commands them and they always do what they're told. "Keeping the family from the fire of Hell have the intent advising them to be obedient, devoted to Allah Almighty believe to Allah only, do not shirk, teach them about the Islamic Shari'a and about morals of Islam. The Sahaba and mufassirin explained about the interpretation of the verse is as follows: 
1. 'Ali bin Abi Talib radhiyallaahu' anhu said, "Teach religion to your families, and teach good morality of Islam."

2. 2. Qatada rahimahullaah said, "Tell your family to obey God! Prevent them from doing sinners. They should carry out the commandments of God and help them out! When you see them do sinners, then prevent and forbid them! "

3. Ibn Jarir Tabari rahimahullaah said: "Teach your family to be obedient to Allah Almighty that (it) can save themselves from the fire of Hell."

4. Imam ash-Syaukani quoting Ibn Jarir: "Mandatory upon us to teach our children the Deen of Islam (Islam), as well as teach kindness and adab-adab of Islam." (Jawas, https://almanhaj.or.id/2082-mengajar-ilmuagama-menasehati-isteri-dengan-cara-yang-baik.html, accessed on 11 Februari 2017) .

In a hadith from Abu Hurairah, the Prophet said, "Admonish the women baik baik, because she was created from the rib, and ribs are the most crooked is the top. If you apply hard to straighten it, you'll break it. But if you let it, it will remain crooked. Therefore, give good advice to the ladies. " (HR. Bukhari and Muslim). This hadith suggests that in giving religious education to the wife, should be done well, wisdom, do not hurt him, but neither let it, too, if his actions do not correspond to religion.

Then, how if a husband is less able to give to his wife religion education that may be caused by the limitations of religious knowledge. In this case KHI provides a solution by suggesting a husband provide an opportunity to learn religion at a woman who probably by bringing in teachers or taking his wife to the majlis science of religion. Knowledge about any subjects that should be given to the husband and wife are not described in detail in KHI. In this case, we can refer to the opinions of scholars about religious knowledge what should be given a husband. According to Hasby Assiddiqiy, a husband should teach about religion, especially syariah issues, such as problems toharah, ablutions, menstruation postpartum, prayer, fasting, dhikr, reading the Quran, do good to a close relative. If a husband is not able to teach himself, he had to give him permission to study outside or bring in a teacher's house, or at least provide reading books. (Assiddiqiy, 2001: 310). According to Imam Assyaukani, a wife should be given lessons on things that are needed in everyday life, about monotheism, polytheism danger, immoral, heart disease and so on. With shar'i education expected of a wife is able to set up housekeeping and educate their children with science syar'i Similarly, set in sickle capable of running the teachings of Islam about domestic life that has teached by the Prophet. Al-Ghazaliy, as quoted Assirbuniy, said that for a person who is already of age, it is obligatory for her first to study kalimat syahadat and understand it. Mandatory for him to know God, who God is, what is the nature and greatness. Then what is intended to obey God like prayer, fasting and alms. If that was complete he learned, then required him to learn sunnah of the Prophet. If it has been learned, then he should learn other things. According Assirbuniy, science sequence that should be known by a good woman (Solehah) is; 1) the science of monotheism and religious issues, 2) knowledge of the Sunnah and adab, 3) science of muamalah and mu'asyarah, especially how devotion to her husband, parents, and educate children, and 4) the sciences useful to the world and hereafter. (Assibuniy, 1419 H: 11-12)

\section{RESEARCH METHOD}

From the point of legal research purposes, this research is a kind of sociological or empirical research. According Soerjono Soekanto, sociological research includes the study of legal identification (unwritten) and research on the effectiveness of the law. (Soekanto, 1986: 51). This research is trying to look into the implementation of the provisions of the Compilation of Islamic Law relating to the duty of the husband to give his wife the religious knowledge among Tablighis in Serdang Bedagai, North Sumatra. Samples were members of Tablighi Jama'at in Serdang Bedagai. The sampling was based on a purposive sampling techniques, by selecting criteria; 1) sample has involved in Tablighi Jama'at more than a year, 2) sample has followed khuruj for 40 days or more. The number of samples required depends on the object and context of the case as well as the information needed. Data collection techniques used were; 1) participatory observation, the researchers conducted observations by following some of the activities Tablighis, 2) interviews were conducted to capture data relating to how they are doing duty as a husband, and 3) documentation. The method used in analyzing the data is qualitative analysis. Because the data analysis used is qualitative analysis, the data acquired is processed using statistical formulas, because it will not find the size scale or table that contains statistical settlement. Actually, the data analysis has been carried out since the start of data collection. Analysis of data from an early age helps to avoid the accumulation of data, making it difficult understanding will again meaning when associated with the research problem. With the steps mentioned above, is expected to be obtained by a thorough overview of the implementation of the obligations as a husband in giving religious education for his wife according to KHI among Tablighis in Serdang Bedagai, North Sumatera. 


\section{IV. \\ DISCUSSION \\ 1. Tablighi Jama'aht Tabligh in a glance}

Tablighi Jama'at born in India, its founder is Sheikh Muhammad Ilyas Kandahlawi (1885-1944) who was born in the village of Kandahlah, Muzhafar Nagar district, North Prades, India. This Jama'at appeared motivated state of Indian Muslims, who was damaged faith and moral degradation devastating. Maulana Muhammad Ilyas was worried condition of the people, especially in the area of Mewat increasingly distant from the values of Islam and lead to a condition characterized by an ignorant society; 1) idolatry, 2) leaving the worship, 3) the mosque no longer function as a center of missionary movement and religion. and, 4) moral damage and 5) immoral acts are spreading. (Suprayetno, Medan Religion Research Journal, Issue 4, December 2006: 8-10). This condition then reinforce his desire to preach then make it happen by forming jama'at movement in 1927, which aims to restore the public in the teachings of Islam. Over time missionary movement is growing rapidly and has spread to various parts of both regions of India as well as to foreign countries. When commenting on the Tablighi Jama'at, Imam Abu Zahrah said many of the Muslims of India who had come out (khuruj) to carry out the Islamic preaching. They bring their own logistics on his back and endure all the hardship for the sake of implementing the islmic preaching that Islam seems to be expanding in some areas of eastern India, also Pilifina and in other places. In fact, in their hands, many people of black Americans to convert to Islam and the Islamic religion flourished there. Thus, continuously, groups of congregation made and moved in India, Pakistan, Indonesia or other countries. (Pirzada, 2003: 28-29)

Tablighi Jama'at developments in Serdang Bedagai Jama'ah is inseparable from the entry to the city of Medan, capital of North Sumatra. Tablighis entrance to the city of Medan begins with the arrival of Maulana Muhammad Ibrahim from Banglore, India in 1971. When he arrived in Medan, he was welcomed by the people of Medan. Some one who is concerned with this missionary movement is Haji Jalaluddin. Maulana Ibrahim was always accompanied by him in conveying his message. They then build a mosque at street Gajah called Masjid Hidayatul Islamiyah Medan, which later became the center (headquarters) Tablighis in Medan. Maulana Ibrahim give his experience to Haji Jalaluddin and later continue his struggle to develop Tablighis in Medan. After Maulana Ibrahim return to his native country, Haji Jalaluddin became amir in Medan. After he died, the post of amir continued by his son, Haji Badruddin until now. (Suprayetno, op.cit: 12). From Masjid Jalan Gajah, Tablighi Jama'at continue to expand to cities and districts in North Sumatra. Various halaqah then stand in many areas, do not miss to Serdang Bedagai area. Serdang Bedagai is a district that was a result of the expansion of Deli Serdang regency, which was inaugurated by the Minister of the Interior on the date. January 7, 2004. With an area of $1900.22 \mathrm{~km} 2$, Serdang Bedagai has 17 districts and 237 villages. In 2008, the population of 618656 inhabitants with compositions ranging from 86.2\% Muslim, 10 Christian, 1\%, Catholic, $3 \%$, Hindu $0.6 \%$, Buddhist $1.2 \%$ and others $0.6 \%$. (Regency Sergai, http://serdang Bedagaikab.go.id/ Indonesia/images/keputusan/perintah.pdf, access February 14, 2017). Now, there are eight halaqah in Serdang Bedagai which are in almost every district like halaqah Pantai Cermin, Dolok Masihul, Sei Rampah, Bedagai, Sipispis. Perbaungan, Sei Rampah dan Serba Jadi. Each Halaqah overshadow various Mahalla in almost every village in the district. It is difficult to ascertain the number of members of the Tablighi Jama'at in Serdang Bedagai because Tablighis do not use the system of administrative formalities membership. The latest data obtained the number of members of the Tablighi Jama'at that have ever followed khuruj 3 days as many as 628 people, 40 days as many as 230 people and 4 months as many as 151 people. (Darmin, interview, February 17, 2017).

\section{Activities of Tabilighi Jama'at and the implementation of Husband's Obligation in Giving Religious Education to his wife}

Those who participate in Tablighis usually called Ahbab, formerly called with karkun. Like in other areas, Tablighis in Serdang Bedagai also follow orderly propaganda that has been outlined from Markaz of the world in Nizamuddin, India. In Tablighis known six principles (doctrine) is a propaganda principles drawn from the essence of the verses of the Koran and the Hadith and the behavior of the lives of the companions of the Prophet Muhammad saw. The six principles are :

1. The sincere and committed declaration of Muslim faith (kalimah tayyibah) which has to be profoundly understood, internalized and practiced by the believing Muslim;

2. The performance of prayer that is profoundly understood and performed with full concentration and humility (salat ma'al-khusu' wa'lkhudu);

3. The practice of dzikir that is for knowledge and dissemination ('ilm ma'a dzikir);

4. Fraternity and respect among and for all Muslims (ikram al-Muslimin);

5. Singularity of purpose and intentionality in devotion (tashih al-niyyah);

6. The willingness and determination to perform missionary work in the company of fellow Muslims (da'wah wa al-tabligh). (Noor, 2012: 76). 
Every Ahbab expected to implement these six principles in everyday life. They are expected to have a strong faith in God and the Prophet Muhammad, prayers with humility 'and humbly, studying as much as possible, along with remembrance as often as possible, glorify fellow Muslims either known or not, straighten the intention solely because God in every practice and carry out missionary work.. In the exercise of perfom missionary, this Jama'ah has different methods contrast with other existing missionary movement. The Jama'ah are encouraged to come out (khuruj) left the family to go to another area, from the mosque to another mosque to bring their own funds, preached the importance of religion. They are recommended at least 3 days each month, 40 days each year and 4 months for life to take the time to khuruj fiy sabilillah. Usually they are formed into a group of $7 \mathrm{~s} / \mathrm{d} 12$ people, led by an emir (leader of the group). Basically, this method of preaching was not merely to preach to others, but it is an attempt to improve themselves (reconciliation) any person who participated in this khuruj. After they return to their families, they have the spirit to be stronger in conducting worship to God and run some activities with great patience, resignation, qanaah and always rely problems of life to religion.adab) according to sunnah the prophet Muhammad saw like how to eat, drink, dress, educate children and the problem of other Islamic law. (Galih Mulyadi, interview, February 18, 2017). Sometimes, the spirit of running the religious laws in these wives often experience many obstacles that might be brought by the bustle in the care of Bernie ladder or other problems.

Under these conditions, the respondents often give advice to his wife to in order to remain strong in conducting religious charity. (Triono, interview, February 12, 2017).-fiil till an-Nas. (Hasan Basri, interview, February 18, 2017). With more good readings to short surah, wife perfom prayer more enjoy and has full concentration. Some respondents also often provide muzakarah (discussion) about some ethics (adab-To find out how far the implementation of obligation of the husband in giving religious education to his wife among Tablighis in Serdang Bedagai, researcher has interviewed several people responnden that they were all of them have ever come out (khuruj) for 40 days and 4 months, and some have already several times khuruj 4 months. All respondents felt that after following khuruj, They felt a fundamental change in the carrying out of religious practice, they feel more religious than before khuruj. They can perform the five of obligatory prayers all, which previously there are still some obligatory prayers that were not implemented for various reasons. Even they can keep obligatory prayer with performing at the beginning of time, with a congregation in the mosque. Not just limited to the obligatory prayers, they were also able perform sunnah prayers like rawatib sunnah prayers, tahajjud prayer, israq prayer, duha prayer and hajat prayer. The characteristics of Islam is also evident in their appearance, such as lengthening beard, wears a head covering, using a turban and gamis, always greeting when met people, and always keep the view. When asked regarding the obligation to provide religious knowledge to the wife, the respondents claimed to have tried to carry it out. Respondents felt higher anxiety about religious life of their wife and children after following Tablighis. They want that their wives become good woman (solehah) and support the missionary movement. The learning process of religious knowledge to wife is conducted by turning ta'lim for an hour every day at home. Usually, ta'lim will be done after the evening prayers, in which the husband read the Book of Fadhilah Amal, while his wife and children also listening. (Mugiroh, interview, February 10, 2017). Book of Fadhilah Amal is witten by Maulana Zakariya containing the primacy reading the Qur'an, prayer virtue, the virtue of remembrance, the primacy of tabligh, the stories of the companions, the collapse of Muslims and how to overcome them and the virtues of Ramadan. The book is read repeatedly in an orderly manner so as husbands, wives and children feel the excitement in the religious charity run after listening to the content of the book. Husband also provide teaching of the Qur'an to the wife in halqah al-Qur'an with a corrected reading short surah that are often used in prayer like surah of al-Fatihah, al

In addition to providing religious education that is done directly by the husband, the respondents also include wives in masturah program. This program is one of the missionary activity specifically targeted to wife of Tablighi Jama'at members .The wife of the Tabighi members also recommended to khuruj with her husband, there is usually 5 to 7 pairs of husband and wife who follow khuruj to other areas. Masturah khuruj program conducted in the mosque for the husband, but the wife of the program carried out in the home around the mosque. The obligation of Tabligh not only for men but also for women.. For that the orderliness of a husband to take his wife encouraged khuruj together within 3 days, 15 days or 40 days. During the program masturah, the wives are given a lot of activities, including:

a. Ta'lim wa ta'lum (learning and teaching)

Nas.-fiil till an-These activities carried out by reading and listening to book of Fadhilah Amal for 4 hours each day. By following these study groups, it is expected there will be a strong spirit in conducting worship to God as prayer, reading the Qur'an, zikir (remembrance of God) and has strong concerns to the people who do not want to practice religion and the spirit of in conducting sunnah of Prophet Muhammad in carrying out this life. 
b. muzakarah (discussion)

Among the items discussed during khuruj masturah are the six principles of the true Sahabat (companions) of the Prophet, 20 principles of preaching (ushul tabligh), preaching directives to men at home (maqomi Rijal), preaching directives to women at home (maqomi masturah), educating the children, faith topics and some ethics (adab

\section{c. Zikr and worship}

During the khuruj masturah, participants are encouraged to perfom fardu prayer at the beginning of time and perform lot of sunnah prayers like duha and tahajjud. In addition, they also recommended a lot of zikr in morning and evening.

\section{d. Bayan (lecture)}

After prayer of ashr, The wives who participate khuruj masturah was given a lecture by the congregation of men who usually concern about the virtues wife solehah, primacy close the genitals, how to increase their faith, stories of the sahabiyah in carrying out the preaching of Islam and ordinances educate children well.

By following this khuruj masturah, wives expected will be able to become leaned ('alimah), educator (murabbiyah), devout ('abidah), the ascetic (zahidah), good server (khadimah) and a preacher (da'iyah). A wife is expected to have a good depth of knowledge in the field of religion and always ready and capable in running ta'lim every day at his home. If the ta'lim were made at home by reciting verses of the Qur'anran and the Hadith of the Prophet, so it is as if his wife and children every day get advice directly from God Almighty and the Holyof prophet Muhammad saw and also all family members have passion in charity and miss for hereafter and the spirit to fight and sacrifice for the religion. Wife also expected to be a good educator that educate their children in accordance with religious values even though at certain moments he is left by her husband to preach. As a servant of God, wife expected could become good worshiper with perfoming prayers at the beginning of time, sunnah prayers, remembrance, read Quran and close the aurah. Then, with khuruj masturah, the wife is also expected to run a simple life, not much demand on husbands somethings less necessary. However, this missionary movement requires a sacrifice of life and property. When wives has more property, They are expected willingly to sacrifice it for the sake of preach of Islam. A wife is also expected to serve her husband in running missionary movement activities. Lastly, the wife is also expected become a woman preacher. Wife had concerns over the condition of the people and invite other women he might meet to take part in a propaganda effort. Then by becoming a preacher, husband and wife are willing to be left for some time to preach.

All respondents felt greatly helped in educating their wives with khuruj masturah program, because not all members of the Tablighi Jama'at is those formally educated religious school. By following this program, husband gives to his wife a chance to learn many things about religion and practice constantly, so the habit during the khuruj will be practiced also in household. Indication of the success of this program can be seen from some of the respondents' experience in the following. After joining the program masturah, wife of respondents to be more observant of worship such as fard prayer at the beginning of time and never leave prayer of sunnah duha.. (Mugiroh, interview, February 10, 2017). There is also the wife of the respondents who were not wearing the hijab (headscarf), after following the program can already wear it when out of his house. (Ka'ab, interview, February 10, 2017). Before participating this propaganda effort, the wife of the respondent is still not perfect in perfoming the obligatory prayers, there were fard prayer left. But after following the program of Tablighi Jama'at, the wife of respondents never leave the fard prayers again. (Interviews, Zainuddin, February 10, 2017). After following khuruj masturah for 15 days, the wife of respondents better at reading the Qur'an and now the neighbor's children came to the house to learn to read the Qur'an to the wife of respondents. (Isak Kudnadi, interview, February 18, 2017). Masturah program's influence was also felt by a respondent who is a professor of religion, educated in the field of Hadith master, which is domiciled in Sei Rampah. He stated, masturah program is very much help the community in shaping the solehah wife. He believes the role of the wife is very dominant in educating children at home, with following this program has increased and the desire to provide religious education to children becoming major priorities. He himself has 5 children, all schools in boarding school of Hafiz al-Quran in North Sumatra and Central Java. (Ust Basuki, Interview, February 13, 2017). Then how the implementation of religious education for the wife if the husband follow khuruj for 40 days or 4 months? Before khuruj, respondents prepare in advance the things that relate to a living form of spending money that should be abandoned and brought for khuruj needs. Then, before leaving, the wife usually invited to follow khuruj masturah forS 3 days or 15 days. Expected when the husband go to preach, the wife can run ta'lim at home every day so that the learning process is not interrupted even though religion husband away for a long time. The experience of a respondent when it came out 40 days, the wife at home even stronger belief in God, better in worhip and constancy in carrying out the ta'lim.. This also happened to their two children who always perform fard prayers in the mosque even though their father was not at home. (Triono, interview, February 12 , 2017). 
From interviews with some respondents the above, it appears that the husband who are members of Tabligh Jama'at in Serdang Bedagai have good attention to religious education and its practice against their wives. There are ta'lim program at home, discussion of religion problems (muzakarah) and following khuruj masturah program as evidence that the husband in addition to providing religious education, also provides learning opportunities to wife.. This is in accordance with one of the obligations of a husband who must be fulfilled as contained in the Compilation of Islamic Law Article 80 verse (3), which reads, "Husband must provide religious education to his wife and provide an opportunity to learn useful knowledge that is beneficial to religion, homeland and nation." So we can say that the duty of the husband to provide religious education well implemented as intended by the Islamic Law Compilation.

\section{CONCLUSION}

As a head of household, a husband has certain obligations to his wife and children. Apparently, in addition to obligations that are living material such as food, clothing and shelter, the husband is also required to provide religious education to his wife and provide learning opportunities that can be useful to religion, homeland and nation. This is in accordance with the provisions of article 80 verse (3) Compilation of Islamic Law. As the Islamic family law that's regulated in Indonesia, this provision bind all the muslim community in Indonesia and no exception to members of Tablighis in Serdang Bedagai, North Sumatera. In family life among Tablighis in Serdang Bedagai found that the husband's obligation to provide religious education to the wife is well implemented. They educate their wife by doing ta'lim program at home, giving muzakarah and religious advice to his wife and children. Even They also provide learning opportunities to their wife through the khuruj masturah program's for 3 days, 15 days and 40 days. The success of the fulfillment of this obligation be seen where the wives of the Tabighi Jama'at more obedient in perfoming prayer, more diligent in reading Qur'an, close the aurah and educate their children with Islamic way

\section{REFERENCES}

[1] Ali, Zainuddin. 2006. Hukum Perdata Islam di Indonesia. Jakarta: Sinar Grafika.

[2] Al-Kandahlawi, Muhammad Zakariyya. Himpunan Fadhilah Amal, ter. Abdurrahman Ahmad.et.al, Yogyakarta: Ash-Shaff.

[3] Assirbuny, Abdurrahman Ahmad. 1419 H, Wanita Shalihah. Cirebon: Pustaka Nabawi.

[4] Assiddiqiy, Muhammad Hasbiy. 2001. Al-Islam. Semarang: PT. Pustaka Rizki Putra

[5] Bisri, Cik Hasani et.al. Kompilasai Hukum Islam dan Peradilan Agama. Jakarta: Logos Wacana Ilmu, 1999.

[6] Departemen Agama RI. Al-Qur'an dan Terjemahnya. Bandung: Gema Risalah Press, 1989.

[7] Jawas, Yazid bin Abdul Qadir, “Hak Isteri Yang Harus Dipenuhi Suami,”https://almanhaj.or.id/2082mengajar-ilmu-agama-menasehati-isteri-dengan-cara-yang-baik.html,(akses 11 Februari 2017)

[8] Pemkab Sergai, Menyikapi (7) Tujuh Perintah Presiden Republik Indonesia ” http:// serdang Bedagaikab.go.id/Indonesia/images/keputusan/perintah.pdf, (akses 14 Februari 2017)

[9] Pirzada, Abdul Khaliq. 2003. Maulana Muhammad Ilyas Rah. a, Di antara Pengikut dan Penentangnya, terj Masrokhan Ahmad. Yogyakarta: Ash-Shaff.

[10] Rahmat Hakim, Hukum Perkawinan Islam. Bandung: Pustaka Setia, 2000.

[11] Rofiq, Ahmad. 1998. Hukum Islam di Indonesia. Jakarta: Raja Grafindo Persada.

[12] Sulaiman, Abi Daud. Sunan Abi Daud. Surabaya: Dar Al-Hadis Himas, t.th..

[13] Suprayetno. “Aktivitas Jama'ah Tabligh di Medan.” Jurnal Penelitian Medan Agama, Edisi 4,(Desember 2006), hal.1-26.

[14] Soekanto, Soerjono. Pengantar Penelitian Hukum. Jakarta: UII Press, 1986.[15] Noor, Farish A. 2012. Islam on the Move: The Tablighi Jama'at in Southeast Asia, Amsterdam: msterdam University Press. 